\title{
Analysis of Using Animal Elements in English Proverbs
}

\author{
Andra Ade Riyanto ${ }^{1}$ \\ ${ }^{1}$ Universitas Gadjah Mada, Indonesia
}

\begin{abstract}
This study aims to describes the function of using animal elements in English proverbs. Proverbs are generally identified from its brief and memorable words or sentences that express truth and reality. Through proverbs it is known that it contains local wisdom, truth, moral values, and traditional views in a fixed and definite, and memorable form of symbolism. The use of animal elements is one of the symbols used in English proverbs. Through proverbs a lot of human behavior was understood through the symbolism of animal behavior in the proverb. Therefore, by understanding the animal simbolism that contained in English proverbs can describe the aspects of human life and the function of the proverbs. The sources of data are collected from book and dictionary of English proverbs and the object of this study were English proverbs with animal figurative elements. This study used descriptive qualitative method. The data were obtained by using the technique of referring and record which was followed by the scanning technique. Data were analyzed using the method of matching (padan). The study found that the function of animal in English proverbs. The function are to praises, advices, reminder, give motivation, and moral formation. This study may be useful in the context of English communicating in order to use the proverbs properly in daily life.
\end{abstract}

Keywords: english proverbs, local wisdom, animals elements, symbol.

\section{Introduction}

Humans use language as a medium of communication in social life to convey messages and intents. Through the language can also be used to convey ideas that exist in the human mind in order to understand each other what is conveyed, not only in oral form but also in written form. [1] said that a language is what was uttered by the community, without any human language can not distribute ideas, thoughts or provide information to others. Thus, in social interaction, people use the language as a communication tool for delivering ideas, thoughts, or information to others. In delivering ideas, thoughts or human information using language, one way to convey it is through proverbs.

Proverb is one form of the result of the human mind that contains elements of culture or wisdom of a society because it is expressed through language. [2] stated that any formation of words and even sentences in a language (including the language in the proverb) can determine the nature or characteristics of the mind in the culture of a nation. Thus, the meaning contained in the proverb can characterize the specific nature of a nation because it is closely related to the culture of native speakers. Proverbs are generally known as a short, sentence of the folk which contains wisdom, truth, moral values, and traditional views in a metaphorical, fixed and definite, and memorizable form which is handed from generations to generation [3].

As a result of human thoughts and experiences, the language used in the proverb cannot be separated from the language form so that in proverbs creation engaging language style or symbolic language used to describe someone or something through comparison. The use of animal elements is one of the symbols used in the proverb. Animals as one of the living creatures have important influences in human life. [4] stated that many of human behavior are understood through the embodiment of animal behavior. Thus, the animal element contained in the proverb can be used as a symbol to describe aspects of human life. The use of animal elements is also used 
in English proverbs because of a close relationship with British society. Here is an example of using animal elements in English proverbs.

\subsection{A Good Horse Never Lacks a Saddle.}

Proverb (1) means being diligent in working. The diligent character is illustrated with a horse that is always ready to work with a saddle mounted on his back. Proverb (1) expresses the hardworking character so it will be always the choice to complete the work which is illustrated by a horse that always fitted with a saddle so that whenever the horse is to be used it will be ready. Thus, this proverb gives advice for someone to have a diligent character and work hard in doing a job.

The use of animal elements in English proverbs are closely related to the geographical conditions and cognitive processes of the society. This situation happened because English proverbs containing local wisdom or social culture of the society. For example, on a proverb that contains the word dog. [5] studied stated that the Western culture perspective of dog is symbolized as a loyal friend to humans and has a close relationship with humans. However, based on [6] studied which stated that in Malay societies a proverb that uses the word dog is viewed as something bad, despicable, and evil so in this case there is a different perspective on the word dog contained in the proverb, depending on the community or context the proverb is used. This phenomenon is in accordance with [7] who stated that proverb is one form of folklore which is the essence of the experience of a linguistic society. This is what causes a different perspective about the word dog in the proverb. Here is an example of using dogs in English proverbs.

\subsection{A Living Dog is better than a Dead Lion.}

The meaning of that proverbs is an animal that performs valuable service to humans. These proverbs contain the advice that a person should be helping each other in life because the meaningful of life is judged by the of roles and the benefits for society, and the person here is often references to dogs. Thus, it can be concluded that the word dog in English proverbs can be symbolized by a positive one.

Based on the background above, the researchers are interested to examine the use of animal elements in English proverbs to reveal its function because there are still many people do not understand the use of English proverbs in interacting in social life. Considering the context of the use and culture of the speakers, the English proverbs of the animal element can be used appropriately. Therefore, research on the use of animal elements in English proverbs need to be done so that the use of these proverbs can be applied in family and community that can be a good guide in life.

\section{Literature Review}

Proverbs are one of the communication tools that is still used in the community and there are the form of cultures and local wisdom for a society that is used from generation to generation. As a means of community communication, proverbs function need to be analyzed because the proverb contains moral values so that the role and use of proverbs in the context of communication can be used properly by the community. [3] has stated that in a proverb contained the values of the wisdom, truth, moral, and traditional views of a community group. This is similar to the concept of [8] who said that all cultural activities are intended to satisfy a sequence of human instinct needs associated with their whole life which is called the function. Thus, the proverb which is part of a society's culture has a function to fulfill a particular purpose.

[3] stated some elements or criterias that must be completed in order that a text can be expressed as a proverb as follows.

(a). A proverb must be in complete form and have a high level of grammatical accuracy;

(b). A proverb is not an out-of-breath utterance but it must be prefabricated and arranged as a broad statement, therefore, the form of a proverb can not be changed; 
(c). The proverbial features are widely known, although the proverb's creators are not clear;

(d). Because of its simple structure and it is composed by metaphorical language, containing rhetorical forms such as alliteration, rhythm, rhyme, etc, then proverbs are very memorable and kept in mind;

(e). Since the proverbs are derived from a collection of human experience or wisdom, they contain prescriptive elements (stating true and false) and contain the teachings of morality; and

(f). Proverbs contain the uncertainty of the semantic meaning of being broadly charged, having broad functions, and having broad semantic meanings as well.

Proverbs are part of a cultural specification within a language society that contains social facts and is shaped according to the pervading culture that has values, traditions, wisdom, and beliefs of a society that is never out of season because of adaptation and innovation that is open to the times [6]. Based on that opinion, the nature of the proverb is open to the development of the era of a shift (misuse), re-confirmed (reuse), even manipulated (abuse) [9]. Thus, the proverb in communication is understood as a text that has the form and meaning that can be observed in terms of linguistics in order to understand the purpose of use and function of the proverb in society.

\section{Methods}

This research is qualitative descriptive by identifying, analyzing and explaining the phenomena of the contained values in the English proverb. The source of data in this research is English proverb dictionary from Oxford Dictionary of Proverbs and book of Concise Dictionary of Proverbs. The selection of these two books as the primary data source of research based on the consideration that two of the book proverbs fairly complete (containing more than 1000 list of proverbs in each book), accompanied by explanations relating to these proverbs and the two books written and published in the UK, so researchers believe that the proverbs in the two books are using the same dialect of the dialect British (British English). In searched the data, the researchers conducted an observation of the use of proverbs from dictionaries and English proverbs book using the method followed by scanning techniques and then noted the data. This is done to categorize and classify data.

Data analysis in this study will be conducted using qualitative research characteristics, the analysis is based on the inductive analysis. This inductive analysis is intended that the analysis of the study will not prove whether a hypothesis is true or false, but compose a conclusion based on the object and theory [10]. The method of the analysis used in this study is the method of interpretation to find the relationship between the use of animal elements in English proverbs with something else that covers it, such as socio-cultural English-speaking community and then to determine the function of the English proverb animal elements among the speakers.

\section{Result and Discussion}

The function of proverbs in communication is to use properly in appropriate context of the communication so that the communication process can run well and hearer can know the intended use of these proverbs. It is in line with [1] who said that the use of proverbs in communications allows us to speak better by taking into account the socio-communicative context in which the incident took place. Therefore, an analysis of the function of the proverb is necessary in order to know the purpose of using the proverb in communication.

Based on the results of data analysis there are several functions of English proverbs that use animal elements. Some of these functions are to convey praise, advice, warning, enthusiasm, and moral formation.

\subsection{Using Proverbs to Deliver Praise}

The purpose of proverbs that function to convey praise is to give appreciation and admiration for something that is considered good, beautiful, handsome, courageous, and so forth. Based on this, the figurative use of animal elements in English proverbs which refers to nature or good behavior, so that it will function as convey praise. Here are some examples of English proverbs that use animal elements used to convey praise. 


\section{A little bait catches a large fish.}

4. Kill two birds with one stone.

The data (3) to (4) above are the example of proverbs that serves to convey praise. Praise is based on excellence or goodness on the source element. Excellence or goodness is reflected in data (3) and (4) which indicates that by using something small or little thing can get many advantages or complete a lot of works with an efficient action so that the person finishes the job quickly.

\subsection{Using Proverbs to Advice}

The purpose of advising in this analysis is to give teachings or suggestions about goodness in the form of clues or admonitions to be understood and implemented properly. Here some representation of the proverbs using to advise.

5. A closed mouth catches no flies.

6. An old fox is not easily snared.

From the above examples, the proverbs know as data that used to convey advice. In the data (5) flies are described as a thing that can cause problems (illness) so we were advised to close the mouth so that flies do not get into the mouth with not too much talk in order not to offend other people. Likewise, with the data (6), foxes in the cognition of British society as ingenious animals so that people assume if the fox animal is aged it has a lot of life experience. Thus, through proverbs (6) serves to advise that to find experience (knowledge) for life in order not easy lied to by others.

\subsection{Using Proverbs to Reminder}

The purpose of a proverb that serves to convey a warning is to give an advice in the form of a message or a warning to be alert, not too confident, and so forth. Here some representation of the proverbs using to deliver a warning.

7. Trust not a horse's heel nor a dog's tooth.

8. Don't count your chickens before they're hatched.

From these two data, proverbs functioned as a means to convey the reminder. In proverb (7) horse shoes and dog teeth in the cognition of British society is a thing that can cause pain so it is described to something dangerous. Therefore, these proverbs appear to give the reminder to be vigilant so that no unwanted things happen. As for proverb (8) which uses the element of chicken to give warning. As for proverb (8) which uses the element of chicken to give warning. Chickens in the British community identify with something that is valuable because if the eggs hatch has high economic values and benefits for life, but if the chicken egg fails to hatch it will result in disappointment because a valuable thing fails to come by. Thus, in proverb (8) it functions as a warning not to be hopeful to the uncertain so that if its failure was not too disappointed.

\subsection{Using Proverbs to Motivate}

The enthusiasm means that the state of mind when the mind is moved to do one or more actions. Thus, enthusiasm has a function as a motivate to do an action. Here are some examples of data representation that serves to convey the enthusiasm.

9. The early bird catches the worm.

10. Use a book as a bee does a flower.

From the data proverbs above are functioning to convey the spirit to others. Proverb (9) uses birds as the source element. In this proverbs bird was described as something diligent to get the food before being taken by other birds. So, if you want to get success or a good thing must do something first so as not taken by others. Thus, the proverb (9) give the spirit to work early or start something good first without having to wait for others 
to gain success and benefit. The proverb (10) using animal elements is a bee. The assumption of English society of bees and flowers are inseparable because it will produce something useful for life. Similarly, if the book is often used properly will provide good benefits for life as well. Therefore, in the proverb (10) serves to provide encouragement to study hard and do not easily get tired of learning (reading book) because it would be very useful in life.

\subsection{Using Proverbs to Moral Formation}

The purpose of proverbs that function to moral formation is the doctrine of good or bad an act, attitude, obligation, and so on. Here are some examples of English animal proverbs that use to moral formation for the community.

11. The world is your cow, but you have to do the milking.

12. Yesterday a cowherd, today a cavalier.

From the data proverbs above are functioning to create a good moral. Proverb (11) uses a cow as the source element. This proverb literally compares the world in which we live and strives like to have a dairy cow, but the cow will not give benefit from providing healthy milk before our own hands do the milking work. This proverb teaches the value of effort and hard work to achieve a certain achievement, not just expecting everything to be available as a facility without any real effort to obtain it. The proverb (12) literally said, yesterday was a shepherd, today became (members of) the cavalry. This proverb clearly implies a spirit of hard work and perseverance that begins with perseverance to simple tasks in order to have constructive experience for greater tasks and future success.

\section{Conclusion}

A proverb is a form of local culture of a nation that expressed through language. Through proverbs, it is known that it contains wisdom, truth, moral values, and traditional views in a fixed and definite, and memorable form of symbolism which is handed down from generation to generation. One of the symbols used in the proverb is the animal element which in life has an important role. From the analysis, it is known that the animal element in English proverb has various functions that are to give praise, advise, give warning, spirit, and moral formation. By knowing the function of the proverb is expected to provide knowledge about the use of animal elements in English proverbs so that it can be used properly in communicating.

\section{Acknowledgements}

This research was funded by Indonesia Endowment for Education (LPDP).

\section{References}

[1] S Barajaz, Elias Dominguez. (2010). The Function of Proverbs in Discourse: The Case of a Mexican Transnational Social Network. Berlin: Dr Gruyter Mouton.

[2] Sibarani, Robert. (2004). Antropologi Lingusitik. Medan: Penerbit Poda.

[3] Mieder, Wolfgang. (2004). Proverb A Handbook. United States of America: Greenwood Press.

[4] Kövesces, Zoltán. (2002). Metaphor: A Practical Introduction. New York: Oxford University Press Inc.

[5] Lakoff, George dan Mark Turner. (1987). More than Cool Reason A Field Guide to Poitec Metaphor. Chicago: University of Chicago Press.

[6] Mieder, Wolfgang. (1993). Proverbs are Never Out of Season. Popular Wisdom in the Modern Age. New York. Oxford University Press. 
[7] Danandjaja, James. (1990). Metode Penelitian Kualitatif dalam Foklor" dalam Pengembangan Penelitian Kualitatif dalam Bidang Bahasa dan Sastra. Malang: Hiski.

[8] Koentjaraningrat. (1990). Pengantar Ilmu Antropologi. Jakarta; rineka Cipta.

[9] Arimi, Sailal. (2016), "Peribahasa Indonesia: Kajian Kategorisasi Struktur dan Vitalitasnya", Dr. Disertation, Universitas Gadjah Mada, Yogyakarta, Indonesia.

[10] Lakoff, George dan Mark Johnson. (1980). Metaphor We Live By. Chicago: The University of Chicago.

[11] Sutopo, HB. (2006). Metodologi Penelitian Kualitatif: Dasar Teori dan Terapannya dalam Penelitian. Surakarta: Universitas Sebelas Maret. 